\title{
Effect of Sunhemp Green Manuring and Intercropping on Soil Properties
}

\author{
Divya Bhayal ${ }^{1}$, V.K. Khaddar ${ }^{1}$, Lalita Bhayal ${ }^{3}$, Tikam Chand Yadav², \\ K.S. Bangar ${ }^{1}$ and Bharat Singh ${ }^{1}$
}

\author{
${ }^{1}$ Department of Soil Science and Agricultural Chemistry, Indore (M.P.) - 452001, India \\ ${ }^{2}$ Department of Soil Science and Agricultural Chemistry, Jawaharlal Nehru Krishi Vishwa \\ Vidhyalya, Jabalpur (M.P.) - 482 004, India \\ ${ }^{3}$ Department of Agronomy, Indore (M.P.) - 452001, India
}

*Corresponding author

\section{Keywords \\ Sun hemp, Green manure, Intercrop, Mean weight diameter, Microbial population}

\section{Article Info}

Accepted:

04 November 2018

Available Online:

10 December 2018

\section{A B S T R A C T}

The field experiment was conducted at the Research Farm of All India Coordinated Research Project for Dryland Agriculture (AICRPDA), College of Agriculture, Indore during kharif 2017. The experiment was laid out in a randomized block design (RBD) with eight treatments in three replications. The treatments studied were: $\mathrm{T}_{1}$-Soybean + sunhemp $(2: 1)$ at $30 \mathrm{~cm} ; \mathrm{T}_{2}$-Soybean + sunhemp $(1: 1)$ at $45 \mathrm{~cm} ; \mathrm{T}_{3}$-Sole soybean at $45 \mathrm{~cm} ; \mathrm{T}_{4^{-}}$ Maize + Sunhemp (2:1) at $45 \mathrm{~cm}$; $\mathrm{T}_{5}$-Maize + Sunhemp (1:1) at $30 \mathrm{~cm}$; $\mathrm{T}_{6}$-Sole Maize at $60 \mathrm{~cm} ; \mathrm{T}_{7}$-Soybean + Maize (1:1) at $45 \mathrm{~cm}$ and $\mathrm{T}_{8}-$ Sole sunhemp at $30 \mathrm{~cm}$. Soybean (JS 95-60) and Maize (K 604 hybrid) were grown as rainfed crops in Kharif 2017 with 20:60:40 and 120:60:40 kg ha ${ }^{-1}$ recommended dose of $\mathrm{N}: \mathrm{P}_{2} \mathrm{O}_{5}: \mathrm{K}_{2} \mathrm{O}$ fertilizers, respectively with Sunhemp as a green manure crop. The soil physio-chemical and microbial properties were studied at crop harvest. The results revealed that the green manuring and intercropping of sunhemp with soybean and maize crop improved the soil physical properties. The soil organic carbon found 20-28\% higher under green manuring and intercropping. The application of green manure showed 13-15\%, 21-36\%, 4-5\% and 3$14 \%$ higher soil available N, P, K and S after harvest of crops indicating increase in the soil available nutrient status. Similarly, the soil available N, P and K showed 7-13\%, 18$35 \%$ and $2-5 \%$ increment under green manure intercropping. The treatments also showed significantly higher soil microbial population irrespective of the spacing and type of crop combinations (soybean/maize).

\section{Introduction}

A fertile and healthy soil is the basis for healthy plants, animals, and humans. The soil organic carbon is the very foundation for healthy and productive soils. The soil organic matter positively influences and modifies almost all the soil properties. Considering the role of soil organic matter in maintaining soil health, the agricultural practices that enhance the soil organic carbon are thus essential. On the other hand, reduced agricultural productivity, escalating production costs, heavy reliance on non-renewable resources, 
reduced microbial diversity, water contamination, chemical residues in food grains and health risk to the population are the major problems in front of the scientists and policy makers throughout the world. Hence it is therefore essential to think for substituting the nutrient requirement of the crops through different organic inputs. The soil organic carbon can be managed by many ways and practices such as regular application of organic manures, agriculture residue management, crop rotation, conservation agriculture, no or reduced tillage, biochar application and green manuring. Each management practice has its benefits and limitations depending upon the topography, climate, soil type, water availability, economic feasibility etc. Among these management practices the green manuring is the most economical and practically applicable method identified for enhancing the soil organic carbon. Addition of organic matter through green manures plays an important role in improving productivity of crop besides improvement in soil physico-chemical properties, which often deteriorate under intensive cropping involving inorganic fertilization (Hiremath and Patel, 1996). The beneficial effects of the green manuring and intercropping have already been studied in various part of the world in different soils and diverse crops (Muza, 1998; Hongal 2001; Hayder et al., 2003) but the information is lacking in a vertisol especially under soybeanmaize intercrop with sunhemp as a green manuring crop. Thus, in order to narrow the identified research gaps a field experiment was conducted.

\section{Materials and Methods}

The experiment was conducted during the kharif season of 2017-18 at the Research Farm of All India Coordinated Research Project for Dryland Agriculture (AICRPDA), College of Agriculture, Indore. The experimental site has almost uniform topography with light to medium black soils and geographically situated in Malwa Plateau in western parts of Madhya Pradesh on $22.43^{\circ} \mathrm{N}$ and $75.66^{\circ} \mathrm{E}$ with an altitude of $556 \mathrm{~m}$ amsl. The site is characterized with dry summers with the rising temperature up to $44^{\circ} \mathrm{C}$ or even higher during April-May. The winters are normal with temperature descending up to $10^{\circ} \mathrm{C}$ or even more during December and January. The average annual rainfall varies from $750 \mathrm{~mm}$ to $1000 \mathrm{~mm}$ and $90 \%$ of this is received during the last week of June, July, August, September and first week of October through South-West monsoon.

\section{The field experiment}

The present field experiment was carried out with 8 treatments replicated thrice in a Randomized Block Design (RBD). The treatments involved $\mathrm{T}_{1}$ (Soybean + sunhemp $(2: 1)$ at $30 \mathrm{~cm}) ; \mathrm{T}_{2}$ (Soybean + sunhemp (1:1) at $45 \mathrm{~cm}$ ); $\mathrm{T}_{3}$ (Sole soybean at $45 \mathrm{~cm}$ ); $\mathrm{T}_{4}$ (Maize + Sunhemp (2:1) at $45 \mathrm{~cm}$ ); $\mathrm{T}_{5}$ (Maize + Sunhemp (1:1) at $30 \mathrm{~cm}) ; \mathrm{T}_{6}$ (Sole Maize at $60 \mathrm{~cm}) ; \mathrm{T}_{7}$ (Soybean + Maize $(1: 1)$ at $\left.45 \mathrm{~cm}\right)$; $\mathrm{T}_{8}$ (Sole sunhemp at $30 \mathrm{~cm}$ ). The green manurung crop sunhemp, soybean (cv. JS 9560 ) and maize (cv. K 604 Hybrid) were sown in the last week of June. The soybean and maize were grown with 20:60:40 and 120:60:40 kg ha-1 recommended dose of $\mathrm{N}$ : $\mathrm{P}_{2} \mathrm{O}_{5}: \mathrm{K}_{2} \mathrm{O}$, respectively. The sunhemp was incorporated in the first week of August. Similarly, the soybean and maize crops were harvested in first week of October and November, respectively at maturity.

\section{Soil sampling and analysis}

Representative composite soil samples (0-15 $\mathrm{cm}$ depth) were collected with the help of stainless steel auger from the experimental plot before sowing and after harvesting of crop. The samples were mixed thoroughly and dried in air, crushed, sieved through $2 \mathrm{~mm}$ sieve. The samples were analyzed for physico- 
chemical and microbial properties following the standard methods. The initial characteristics of the soil of the experimental field are given in Table 1. The soil bulk density was determined by collecting the soil cores with manually operated core sampler. The drawn core samples were dried in the oven at $105^{\circ} \mathrm{C}$ for 24 hours and then dry weights were recorded. The bulk density was calculated as unit weight per volume outlined by Richards et al., (1954). The soil samples from various treatments were collected with $10 \mathrm{~cm}$ increments up to a depth of $30 \mathrm{~cm}$, with the help of a tube auger and the moisture content was determined by gravimetric method. The mean weight diameter of aggregates was calculated by following the procedure given by Yoder (1936) in which soil sample from each treatment were collected from $10 \mathrm{~cm}$ depth. At the time of sampling, soil samples were broken gently with cleavage and air dried in the laboratory. Air-dried samples were passed through $8 \mathrm{~mm}$ sieve. The samples were cleaned by removing roots, lime concretions, etc. The nest of five sieves having 5,2,1,0.5 and $0.25 \mathrm{~mm}$ openings was sieve holders in the Yoder type wet sieving machine. Air -dried triplicate soil samples were used for the analysis. Out of them, one sample was kept for moisture content estimation and the remaining two were used for aggregate analysis. Soil sample was placed on $5 \mathrm{~mm}$ sieve of the sieve set and was moist by a mist of water. Then sieve set was placed in Yoder type wet sieving machine. Immediately prior to sieving water level was raised rapidly to a point where it fairly covered the sample when the sieves were in their highest position. Subsequently, the Yoder`s wet sieving procedure was followed and the MWD was calculated as follows:

Mean weight diameter $(M W D)=\sum_{i=1}^{n}(d i \times W i)$

Where, $\mathrm{n}=$ number of size fraction; $\mathrm{di}=$ mean diameter of each size range; $\mathrm{Wi}=$ fraction weight of aggregate in that size range of total dry weight of the sample analyzed.

Soil porosity was calculated using particle and bulk density of the soil. The soil $\mathrm{pH}$ was determined in (1:2) soil: water suspension using $\mathrm{pH}$ meter with glass electrode (Piper, 1950). Soil electrical conductivity was determined in the supernatant solution 1:2 soil: water suspension using electrical conductivity meter (Piper, 1950). Soil organic carbon was estimated by the Walkley and Black (1934) method. The soil available nitrogen was estimated by alkaline permanganate method (Subbiah and Asija, 1956). The determination of available phosphorus was done by using Olsen's reagent $(0.5 \mathrm{~N}$ sodium bicarbonate solution of $\mathrm{pH} 8.5)$ as stannous chloride reduced to blue colour, which is in proportion to the concentration of phosphate. The measurement was carried out using the spectrophotometer (Olsen et al., 1954). The soil available potassium was determined by using $1 \mathrm{~N}$ neutral ammonium acetate solution using flame photometer (Jackson, 1973). For determination of the soil available sulphur, soil was shaken with $0.15 \%$ $\mathrm{CaCl}_{2}$ solution. The filtrate was analyzed for sulphur in which the turbidity produced due to precipitation of sulphate as barium sulphate measured on a spectrophotometer at a wave length of $420 \mathrm{~nm}$ (Bradley and Lancaster, 1960). The soil microbial population was studied using different dilution methods. The samples were incubated using suitable media for respective microorganisms. The composition of the media used for studying different microorganisms are given in Table 2.

The data obtained were tabulated and subjected to statistical analysis of variance using the method suggested by Panse and Sukhatme (1967). The experimental data was statistically analyzed by adopting randomized 
block design. The critical difference values were computed at $5 \%$ level.

\section{Results and Discussion}

\section{Soil physical properties}

The data pertaining to the effect of green manuring and intercropping on soil physical properties viz. soil moisture, bulk density, soil porosity and mean weight diameter (MWD) has been presented in Table 3 .

\section{Soil moisture}

The soil moisture content before and after harvest of the crop at $0-15 \mathrm{~cm}$ and $15-30 \mathrm{~cm}$ depth under different treatments has been shown in Table 3 . The data revealed that, the soil moisture content before sowing in 0-15 $\mathrm{cm}$ and $15-30 \mathrm{~cm}$ soil depth was ranged $28.00-$ $32.27 \%$ and $29.90-34.17 \%$, respectively. The soil moisture after harvest in $0-15 \mathrm{~cm}$ and $15-$ $30 \mathrm{~cm}$ ranged $16-24 \%$ and $17.67-24.67 \%$, respectively under different treatments. In 0$15 \mathrm{~cm}$ soil depth, highest soil moisture content was observed in the treatment $\mathrm{T}_{8}$ (Sole sunhemp at $30 \mathrm{~cm}$ ) followed by treatment $\mathrm{T}_{2}$ (Soybean + sunhemp $(1: 1)$ at $45 \mathrm{~cm})$. The lowest soil moisture content was observed in the treatment $\mathrm{T}_{6}$ in which sole maize was grown at $60 \mathrm{~cm}$ row to row spacing. The data revealed that, the soil moisture content after harvest in $0-15 \mathrm{~cm}$ was found to be $17-36 \%$ higher under green manuring in soybean crop while it was 20-35\% higher under green manuring in maize crop than sole soybean and maize crop, respectively. Similarly, in 15-30 $\mathrm{cm}$ soil depth, the increment was $19-30 \%$ and $15-28 \%$ higher under soybean and maize crop, respectively as compared to respective sole cropping. The sole sunhemp cropping registered $35-40 \%$ and $33-37 \%$ higher soil moisture in $0-15$ and $15-30 \mathrm{~cm}$ soil depth, respectively as compared to sole soybean and maize crop. The intercropping also showed
20-26\% higher soil moisture in different depths as compared to sole cropping. Thus, the green manuring resulted in retention of soil moisture as compared to sole cropping. The maize grown at $60 \mathrm{~cm}$ row to row spacing showed lowest soil moisture in both the depth studied. The reduction of soil moisture in $0-15$ $\mathrm{cm}$ soil depth was observed with the increase in row to row spacing. Similarly, the absence of green manuring crop also resulted in reduction in soil moisture content. Tsubo and Walker (2002) measured photosynthetic radiation above and beneath a maize-bean intercrop canopy and observed that the canopy reduces the soil evaporation resulting more moisture retention. This might explain the intercrop advantage on soil moisture retension. The intercropping utilizes available resources efficiently compared with each sole crop of the mixture (Dhima et al., 2007; MucheruMuna et al., 2010). Sharma et al., (2010) and Ghanbari et al., (2010) also found similar results.

\section{Soil bulk density}

The soil bulk density before sowing of crops ranged 1.22-1.27 $\mathrm{Mg} \mathrm{m}^{-3}$ whereas it was ranged 1.31-1.40 $\mathrm{Mg} \mathrm{m}^{-3}$ after harvest of the crops (Table 3 ). The soil bulk density was found lowest in the treatment $\mathrm{T}_{8}$ (Sole sunhemp at $30 \mathrm{~cm}$ ). The highest soil bulk density was observed in the treatment $\mathrm{T}_{3}(1.40$ $\left.\mathrm{Mg} \mathrm{m}^{-3}\right)$ in which sole soybean was grown at $45 \mathrm{~cm}$ row to row spacing. The soil bulk density in treatment $\mathrm{T}_{8}$ significantly reduced over the other treatments. Similarly, the treatments involving the intercropping of sunhemp $\left(\mathrm{T}_{1}, \mathrm{~T}_{2}, \mathrm{~T}_{4}\right.$ and $\left.\mathrm{T}_{5}\right)$ showed significant reduction in soil bulk density over the treatments with sole cropping and/or without sunhemp $\left(\mathrm{T}_{3}, \mathrm{~T}_{6}\right.$ and $\left.\mathrm{T}_{7}\right)$. The sole sunhemp incorporation (Treatment $\mathrm{T}_{8}$ ) resulted in significant reduction in bulk density of soil (5-10\% reduction). Similarly, the soil bulk density was found to be $2-3 \%$ 
and $1 \%$ lower under soybean and maize green manure incorporation as compared to the sole cropping (Table 3 ).

The soil bulk density is an important characteristic for successful root development (Kuchenbuch and Ingram, 2004). The reduction in soil bulk density was mainly attributed to the increase in soil organic carbon content (Tiarks et al., 1974) due to incorporation of green manure. The soil organic carbon content is inversely proportional to bulk density (Baur and Black, 1994) which helps in improving the soil structure, soil aggregation, and a consequent increase in volume of micropores resulting in reduction in bulk density. Green manuring incorporation results in decreased bulk density, increased water stable aggregates, pore space, water intake and water retention (Selvi and Kalpana, 2009). The results of present study are in close agreement with the findings observed by Sharma et al., (2010).

\section{Soil porosity}

The soil porosity analyzed after harvest of the crops ranged between $47.4 \%$ in treatment $\mathrm{T}_{6}$ and $51.3 \%$ in treatment $\mathrm{T}_{8}$ among different treatments under study (Table 3). The soil porosity remained unaffected irrespective either intercropping and/or green manuring. Soil porosity is the characteristic determined by the amount of pore, or open space between soil particles and generally not affected in short span of time. Selvi and Kalpana (2009) recorded similar findings with respect to the soil porosity.

\section{Mean Weight Diameter (MWD)}

The MWD was significantly influenced by green manure incorporation and green manure intercropping. The MWD was ranged between $0.67 \mathrm{~mm}$ in treatment $\mathrm{T}_{6}$ and $1.59 \mathrm{~mm}$ in treatment $\mathrm{T}_{8}$ among different treatments under study. The treatments $T_{1}, T_{2}$ and $T_{8}$ was found to be statistically at par with respect to the MWD but significantly superior over the other treatments under study. Similarly, the treatments $\mathrm{T}_{3}, \mathrm{~T}_{4}, \mathrm{~T}_{5}, \mathrm{~T}_{6}$ and $\mathrm{T}_{7}$ were also found statistically at par with each other. The application of green manure (incorporation of sole sunhemp) showed 67-127\% higher MWD after harvest of crops indicating increase in the MWD. Similarly, the MWD under soybean+sunhemp and maize+sunhemp showed $107-113 \%$ and $21-31 \%$ increase as compared to sole soybean and sole maize, respectively (Table 3 ). It has been observed that the intercropping of soybean with green manure $\left(\mathrm{T}_{1}\right.$ and $\left.\mathrm{T}_{2}\right)$ showed significantly higher MWD as compared to the intercropping of green manure with maize $\left(\mathrm{T}_{4}\right.$ and $\left.\mathrm{T}_{5}\right)$. The increase in MWD of soil was mainly attributed to the increase in soil organic carbon content (Tiarks et al., 1974) due to incorporation of green manure. The soil organic carbon helps in improving the soil structure, soil aggregation, and a consequent increase in volume of micropores resulting higher MWD. Similar results were obtained by Selvi and Kalpana (2009) and Sharma et al., (2010).

\section{Soil chemical properties}

\section{Soil pH and EC}

The soil $\mathrm{pH}$ ranged between 7.26-7.53 among different treatments under study. The soil $\mathrm{pH}$ remained unaffected irrespective either intercropping and/or green manuring. The soil electrical conductivity (EC) after harvest of soybean, maize and sunhemp (green manuring crop) found reduced but not significantly affected. It was ranged between $0.19 \mathrm{dS} \mathrm{m}^{-1}$ and $0.25 \mathrm{dS} \mathrm{m}^{-1}$ among different treatments (Table 4). Soil $\mathrm{pH}$ and EC are the characteristics determined by parent material and generally not affected in short span of time. Similar results were obtained by Singh et al., (2008). However, a decrease soil pH with 
application of green manures in long term has been reported by Kumar and Singh (2010) and Subehia and Dhanika (2013).

\section{Soil organic carbon}

The soil organic carbon after harvest of the crops ranged between $0.42 \%$ and $0.50 \%$ under different treatments (Table 4). The treatment $\mathrm{T}_{8}$ (sole sunhemp at $30 \mathrm{~cm}$ ), $\mathrm{T}_{2}$ (Soybean + sunhemp (1:1) at $45 \mathrm{~cm}), \mathrm{T}_{1}, \mathrm{~T}_{4}$ and $\mathrm{T}_{5}$ recorded significantly higher soil organic carbon as compared to the other treatments. The treatments without green manuring crop i.e. $T_{3}, T_{6}$ and $T_{7}$ showed significantly lower soil organic carbon. Thus, incorporation of green manure in plot significantly improved the organic carbon status of the soil.

The treatment $\mathrm{T}_{8}$ (sole sunhemp at $30 \mathrm{~cm}$ ) registered $20-28 \%$ higher soil organic carbon as compared to the sole soybean and maize cropping. Similarly, the sunhemp incorporation either with soybean or maize (Treatment $\mathrm{T}_{2}, \mathrm{~T}_{1}, \mathrm{~T}_{4}$ and $\mathrm{T}_{5}$ ) recorded significantly higher soil organic carbon as compared to the sole soybean and maize crops (Treatment $\mathrm{T}_{3}$ and $\mathrm{T}_{6}$ ). These treatments registered an increment of $20-28 \%$ in soil organic carbon content. Thus, incorporation of green manure in plot significantly improved the organic carbon status of the soil. The observed increase in SOC might be due to the buildup of carbon in soil as present experiment involved incorporation of phytomass of green manure. The sunhemp green manure crop produces 8.1-37.5 $\mathrm{t} \mathrm{ha}^{-1}$ phytomass (Bin, 1983) and 3.2-6.3 $\mathrm{t} \mathrm{ha}^{-1}$ dry biomass (Bharadwaj et al., 1981). Besides the green manure incorporation, the root biomass and left over stubbles have also contributed to the increment in soil organic carbon (Aher et al., 2015). Green manure builds up considerable soil organic carbon due to the addition of phytomass and biomass (Selvi and Kalpana, 2009). It was observed that soil organic carbon content in different soil layer in plots with green manuring increased to the extent of 25 to $50 \%$ as compared to no green manuring (Sur et al., 1993; Sharma et al., 2000; Hebbi, 2000). Similar results were obtained by Aulakh et al., (2001) and Chand et al., (2011).

\section{Soil available nutrients $(\mathrm{N}, \mathrm{P}, \mathrm{K}$ and $\mathrm{S})$}

The soil available $\mathrm{N}$ before sowing of crops $205 \mathrm{~kg} \mathrm{ha}^{-1}$ whereas it was ranged between 208.09 and $238.03 \mathrm{~kg} \mathrm{ha}^{-1}$ after harvest of crops indicating increase in the soil available $\mathrm{N}$ status. The soil available $\mathrm{N}$ was significantly influenced by the application of green manure either alone or with intercropping with either soybean or maize. The treatments involving the sole or intercropping of sunhemp (green manure crop) showed significantly higher soil available $\mathrm{N}$ after harvest of the crops as compared to the treatments without green manure incorporation. The treatments involving intercrop of green manure with soybean $\left(\mathrm{T}_{1}\right.$ and $\mathrm{T}_{2}$ ) reported significantly higher soil available $\mathrm{N}$ as compared to the green manure intercrop with maize $\left(T_{4}\right.$ and $\left.T_{5}\right)$ irrespective of spacing. Soil available $\mathrm{P}$ before sowing of the crops was found in the $10.4 \mathrm{~kg} \mathrm{ha}^{-1}$ whereas it was found between $10.49-16.45 \mathrm{~kg}$ $\mathrm{ha}^{-1}$ after harvest of crops under different treatments. The treatments $\mathrm{T}_{1}, \mathrm{~T}_{2}, \mathrm{~T}_{5}$ and $\mathrm{T}_{8}$ found at par with respect to the soil available $\mathrm{P}$ in soil but significantly superior over the other treatments $\left(\mathrm{T}_{3}, \mathrm{~T}_{4}, \mathrm{~T}_{6}\right.$ and $\left.\mathrm{T}_{7}\right)$. The treatment $T_{7}$ recorded lowest soil available $P$ (10.49 $\left.\mathrm{kg} \mathrm{ha}^{-1}\right)$. The soil available $\mathrm{P}$ was found in the order: $\mathrm{T}_{8}>\mathrm{T}_{2}>\mathrm{T}_{1}>\mathrm{T}_{5}>\mathrm{T}_{4}>\mathrm{T}_{3}>\mathrm{T}_{6}>\mathrm{T}_{7}$ (Table 4). The soil available potassium before sowing of crops was observed $560 \mathrm{~kg} \mathrm{ha}^{-1}$. The soil available $\mathrm{K}$ after harvest of crops was significantly influenced by intercropping and green manure incorporation in the different 
treatments. The treatments $T_{1}, T_{2}, T_{4}, T_{5}$ and $\mathrm{T}_{8}$ were found to be statistically at par but statistically significant over the other treatments with respect to available $\mathrm{K}$ in soil. The treatments involving the incorporation of sunhemp as green manure either sole or as intercrop showed higher soil available $\mathrm{K}$ as compared to the other treatments (Table 4). The soil available Sulphur after harvest of crops ranged between 13.03-15.47 kg ha ${ }^{1}$.The treatments $\mathrm{T}_{1}, \mathrm{~T}_{2}, \mathrm{~T}_{4}, \mathrm{~T}_{5}$ and were also found statistically at par (Table 4). The application of green manure (incorporation of sole sunhemp) showed 13-15\%, 21-36\%, 4$5 \%$ and $3-14 \%$ higher soil available N, P, K and $\mathrm{S}$ after harvest of crops indicating increase in the soil available nutrient status. The soil available $\mathrm{N}$ showed $9-11 \%$ and $7-9 \%$ higher under soybean+ sunhemp and maize + sunhemp as compared to sole soybean and sole maize, respectively. The soil available $\mathrm{P}$ also showed 18-35\% increment under soybean+ sunhemp green manure intercropping whereas the increment in case of maize + sunhemp intercropping was 3$24 \%$. The soil available $\mathrm{S}$ was not much benefited from the green manuring due to high initial $\mathrm{S}$ status of the experimental soil. The soil available $\mathrm{K}$ also showed an increment of $3-5 \%$ and $2-5 \%$ under soybean and maize green manure intercropping. Thus, the soil available nutrients were significantly influenced by the application of green manure either alone or with intercropping with either soybean or maize as compared to sole soybean and maize cropping. It has been observed that the incorporation of green manure as sole crop or as intercrop with either soybean or maize found beneficial with respect to the improvement in soil properties viz. soil bulk density, moisture content, organic carbon, and availability of major nutrients $(\mathrm{N}, \mathrm{P}, \mathrm{K}$ and $\mathrm{S})$ as compared to the treatments without green manure.

The average increase in available nitrogen, phosphorous and potassium was around 40, 90 and $38 \%$ respectively, over initial status of soil (Hebbi, 2000). The sunhemp green manure crop produces $8.1-37.5 \mathrm{t} \mathrm{ha}^{-1}$ phytomass (Bin, 1983), 3.2-6.3 $\mathrm{t} \mathrm{ha}^{-1}$ dry biomass (Bharadwaj et al., 1981) and accumulates 42-95 $\mathrm{kg} \mathrm{ha}^{-1} \mathrm{~N}$ (Mishra and Nayak, 2004; Selvi and Kalpana, 2009).

Table.1 Initial soil properties of experimental field

\begin{tabular}{|c|c|}
\hline Soil property & Value \\
\hline Sand $(\%)$ & 10.5 \\
\hline Clay $(\%)$ & 38.3 \\
\hline Silt $(\%)$ & 51.3 \\
\hline Electrical conductivity $\left(\mathrm{dS} \mathrm{m}^{-1}\right)$ & 0.41 \\
\hline Soil pH & 7.41 \\
\hline Organic Carbon (\%) & 0.46 \\
\hline Available Nitrogen $\left(\mathrm{kg} \mathrm{ha}^{-1}\right)$ & 191.8 \\
\hline Available Phosphorus (kg ha $\left.{ }^{-1}\right)$ & 12.16 \\
\hline Available Potassium (kg ha $\left.{ }^{-1}\right)$ & 573.9 \\
\hline Available Sulphur $\left(\mathrm{kg} \mathrm{ha}^{-1}\right)$ & 15.0 \\
\hline Bacteria $\left(\times 10^{6}\right)$ & 14.6 \\
\hline Fungi $\left(\times 10^{3}\right)$ & 12.4 \\
\hline Actinomycetes $\left(\times 10^{4}\right)$ & 12.6 \\
\hline
\end{tabular}


Table. 2 Chemical composition of standard media for fungi, bacteria and actinomycetes

\begin{tabular}{|c|c|c|c|}
\hline $\begin{array}{l}\text { Chemical } \\
\text { composition }\end{array}$ & $\begin{array}{l}\text { Rose Bengal } \\
\text { (Fungi) }\end{array}$ & $\begin{array}{l}\text { Thorntons media } \\
\text { (Bacteria) }\end{array}$ & $\begin{array}{l}\text { Caseinate Agar Media } \\
\text { (Actinomycetes) }\end{array}$ \\
\hline Glucose & $10 \mathrm{gm}$ & - & - \\
\hline Peptone & $5 \mathrm{gm}$ & - & - \\
\hline $\mathrm{KH}_{2} \mathrm{PO}_{4}$ & $1 \mathrm{gm}$ & - & $0.5 \mathrm{gm}$ \\
\hline $\mathrm{MgSO}_{4}$ & $0.03 \mathrm{gm}$ & $0.2 \mathrm{gm}$ & $0.2 \mathrm{gm}$ \\
\hline Agar-Agar & $15-18 \mathrm{gm}$ & $15-18 \mathrm{gm}$ & $15-18 \mathrm{gm}$ \\
\hline Distilled water & $1000 \mathrm{ml}$ & $1000 \mathrm{ml}$ & $1000 \mathrm{ml}$ \\
\hline $\mathrm{CaCl}_{2}$ & - & $0.2 \mathrm{gm}$ & - \\
\hline $\mathrm{FeCl}_{2}$ & - & Trace & - \\
\hline $\mathrm{NaCl}_{2}$ & - & $0.1 \mathrm{gm}$ & - \\
\hline $\mathrm{KNO}_{3}$ & - & $0.5 \mathrm{gm}$ & - \\
\hline Asparagin & - & $0.5 \mathrm{gm}$ & - \\
\hline Mannitol & - & $1 \mathrm{gm}$ & - \\
\hline Yeast extract & - & Trace & - \\
\hline Sodium Caseinate & - & $0.2 \mathrm{gm}$ & - \\
\hline $\mathrm{FeCl}_{3}$ & - & $0.01 \mathrm{gm}$ & - \\
\hline
\end{tabular}

Table.3 Soil physical properties as influenced by green manuring and intercropping

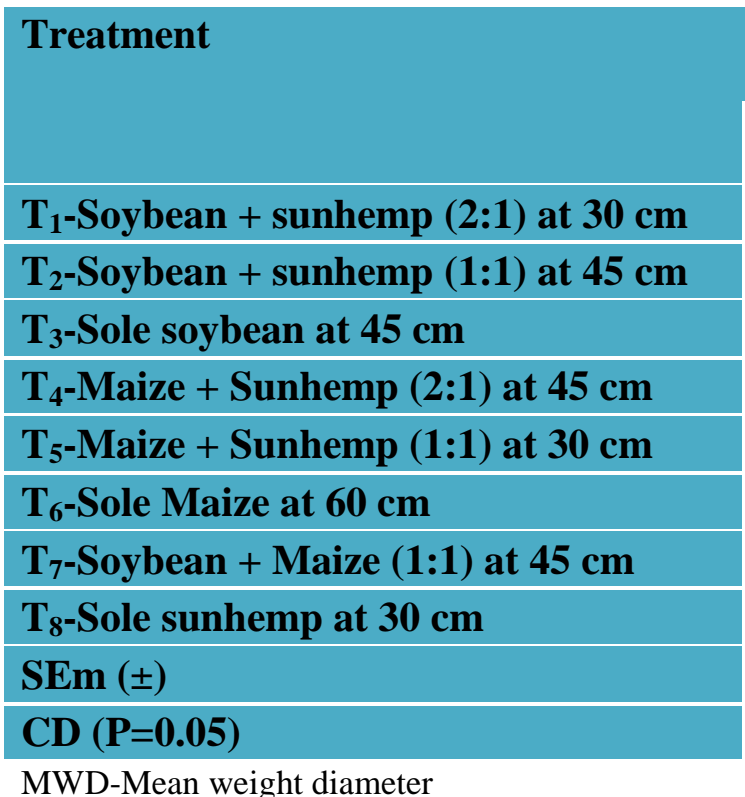

Treatment

MWD-Mean weight diameter

\begin{tabular}{|c|c|c|c|c|}
\hline \multicolumn{2}{|c|}{ Moisture (\%) } & $\begin{array}{c}\text { Bulk density } \\
\left(\mathbf{M g ~ m}^{-3}\right)\end{array}$ & $\begin{array}{c}\text { MWD } \\
(\mathbf{m m})\end{array}$ & $\begin{array}{c}\text { Porosity } \\
(\%)\end{array}$ \\
\hline $0-15$ & $15-30$ & & 1.49 & 50.88 \\
\hline 20.3 & 22.3 & 1.36 & 1.45 & 50.87 \\
\hline 23.7 & 24.3 & 1.35 & 0.70 & 48.57 \\
\hline 17.3 & 18.7 & 1.40 & 0.81 & 49.23 \\
\hline 19.3 & 20.3 & 1.37 & 0.88 & 49.10 \\
\hline 21.7 & 22.7 & 1.36 & 0.67 & 47.40 \\
\hline 16.0 & 17.7 & 1.38 & 0.95 & 49.07 \\
\hline 19.0 & 20.7 & 1.38 & 1.59 & 51.30 \\
\hline 24.0 & 24.7 & 1.31 & 0.11 & 1.04 \\
\hline 1.22 & 1.45 & 0.015 & 0.33 & NS \\
\hline 3.71 & 4.4 & 0.048 & & \\
\hline & & & & \\
\hline
\end{tabular}


Table.4 Soil chemical properties as influenced by green manuring and intercropping

\begin{tabular}{|c|c|c|c|c|c|c|c|}
\hline Treatment & pH & EC & $\mathrm{OC}$ & $\mathbf{N}$ & $\mathbf{P}$ & $\mathbf{K}$ & $\mathbf{S}$ \\
\hline $\mathrm{T}_{1}$-Soybean + sunhemp (2:1) at $30 \mathrm{~cm}$ & 7.38 & 0.22 & 0.56 & 228.0 & 16.1 & 582.3 & 15.3 \\
\hline$T_{2}$-Soybean + sunhemp (1:1) at $45 \mathrm{~cm}$ & 7.53 & 0.20 & 0.58 & 234.0 & 16.3 & 585.5 & 15.5 \\
\hline $\mathrm{T}_{3}$-Sole soybean at $45 \mathrm{~cm}$ & 7.43 & 0.24 & 0.49 & 209.0 & 13.6 & 563.4 & 13.9 \\
\hline $\mathrm{T}_{4}$-Maize + Sunhemp (2:1) at $45 \mathrm{~cm}$ & 7.44 & 0.21 & 0.53 & 222.1 & 14.0 & 575.2 & 14.6 \\
\hline $\mathrm{T}_{5}$-Maize + Sunhemp (1:1) at $30 \mathrm{~cm}$ & 7.45 & 0.23 & 0.55 & 225.1 & 14.9 & 579.4 & 14.7 \\
\hline $\mathrm{T}_{6}$-Sole Maize at $60 \mathrm{~cm}$ & 7.38 & 0.25 & 0.42 & 206.6 & 12.1 & 561.2 & 13.0 \\
\hline $\mathrm{T}_{7}$-Soybean + Maize (1:1) at $45 \mathrm{~cm}$ & 7.51 & 0.23 & 0.44 & 208.1 & 10.5 & 561.2 & 13.4 \\
\hline $\mathrm{T}_{8}$-Sole sunhemp at $30 \mathrm{~cm}$ & 7.26 & 0.19 & 0.59 & 238.0 & 16.5 & 588.7 & 14.3 \\
\hline $\operatorname{SEm}( \pm)$ & 0.06 & 0.02 & 0.03 & 4.8 & 0.7 & 6.4 & 0.5 \\
\hline $\mathrm{CD}(\mathrm{P}=\mathbf{0 . 0 5})$ & NS & NS & 0.10 & 14.4 & 2.0 & 20.1 & 1.5 \\
\hline Initial status & 7.49 & 0.42 & 0.46 & 205.0 & 10.4 & 560.0 & 13.7 \\
\hline
\end{tabular}

EC- Electrical conductivity ( $\mathrm{dS} \mathrm{m}^{-1}$ ); OC- Organic carbon (\%); N, P, K and S- Available nitrogen, phosphorous, potassium and sulphur, respectively $\left(\mathrm{kg} \mathrm{ha}^{-1}\right)$

Figure.1 Soil bacterial population under green manuring and intercropping treatments at crop harvest (T1-Soybean + sunhemp (2:1) at $30 \mathrm{~cm}$; T2-Soybean + sunhemp (1:1) at $45 \mathrm{~cm}$; T3-Sole soybean at $45 \mathrm{~cm}$; T4-Maize + Sunhemp (2:1) at $45 \mathrm{~cm}$; T5-Maize + Sunhemp (1:1) at $30 \mathrm{~cm}$; T6-Sole Maize at $60 \mathrm{~cm}$; T7-Soybean + Maize (1:1) at $45 \mathrm{~cm}$; T8-Sole sunhemp at $30 \mathrm{~cm}$;

$$
\left.C D_{0.05}=7.96\right)
$$

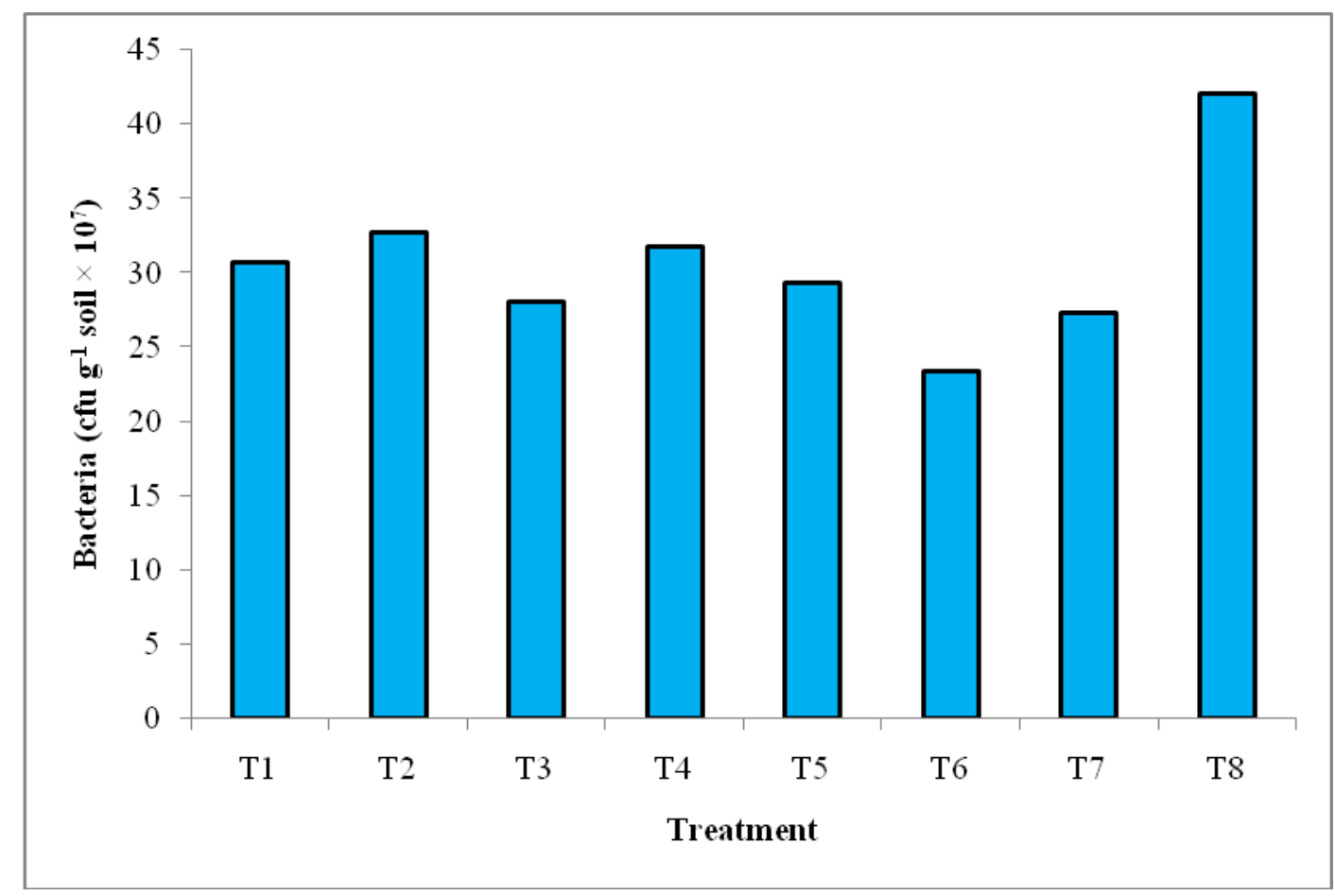

Figure.2 Soil fungal population under green manuring and intercropping treatments at crop 
harvest (T1-Soybean + sunhemp (2:1) at $30 \mathrm{~cm}$; T2-Soybean + sunhemp (1:1) at $45 \mathrm{~cm}$; T3-Sole soybean at $45 \mathrm{~cm}$; T4-Maize + Sunhemp (2:1) at $45 \mathrm{~cm}$; T5-Maize + Sunhemp (1:1) at $30 \mathrm{~cm}$; T6-Sole Maize at $60 \mathrm{~cm}$; T7-Soybean + Maize (1:1) at $45 \mathrm{~cm}$; T8-Sole sunhemp at $30 \mathrm{~cm}$;

$$
C D_{0.05}=2.42 \text { ) }
$$

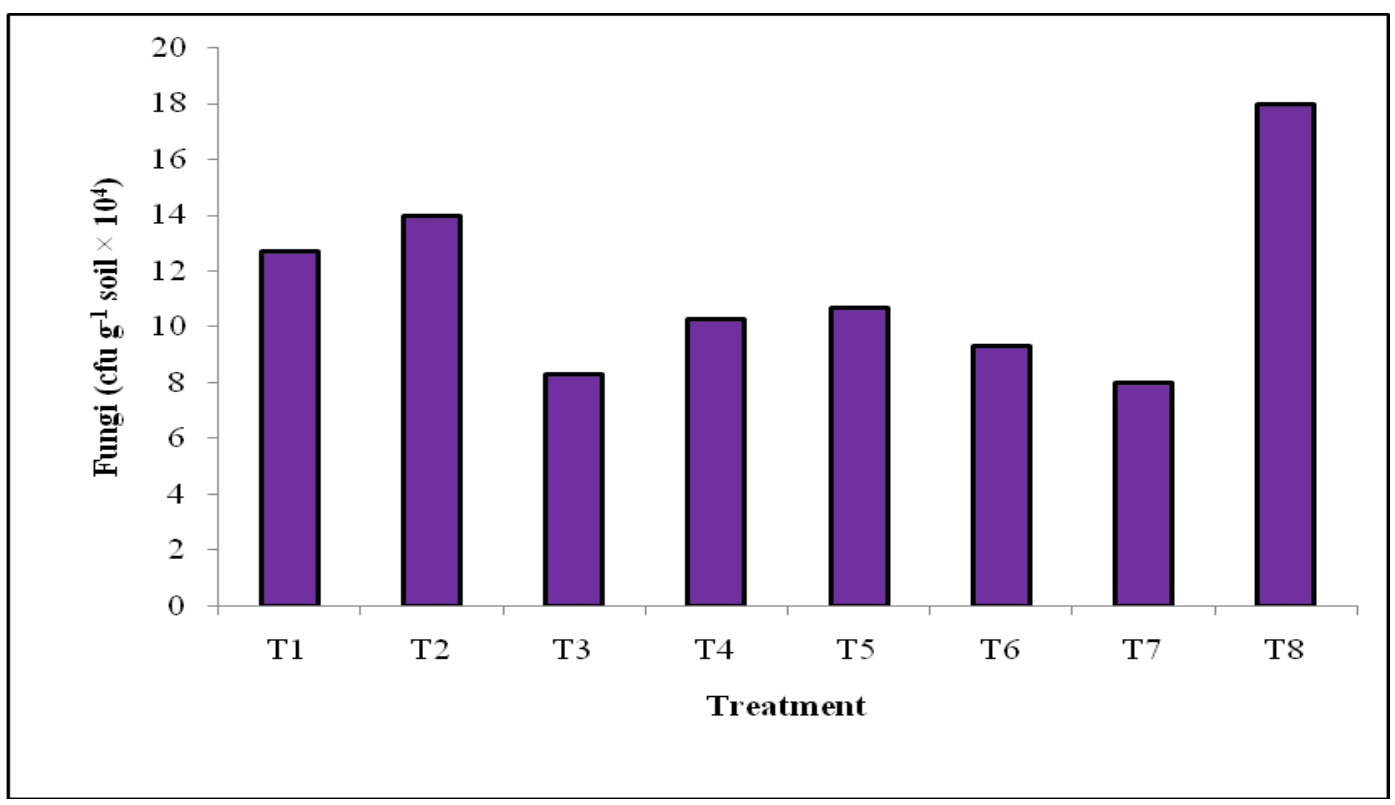

Figure.3 Soil actinomycetes population under green manuring and intercropping treatments at crop harvest (T1-Soybean + sunhemp (2:1) at $30 \mathrm{~cm}$; T2-Soybean + sunhemp (1:1) at $45 \mathrm{~cm}$; T3Sole soybean at $45 \mathrm{~cm}$; T4-Maize + Sunhemp (2:1) at $45 \mathrm{~cm}$; T5-Maize + Sunhemp (1:1) at 30 cm; T6-Sole Maize at $60 \mathrm{~cm}$; T7-Soybean + Maize (1:1) at $45 \mathrm{~cm}$; T8-Sole sunhemp at $30 \mathrm{~cm}$;

$C D_{0.05}=2.64$ )

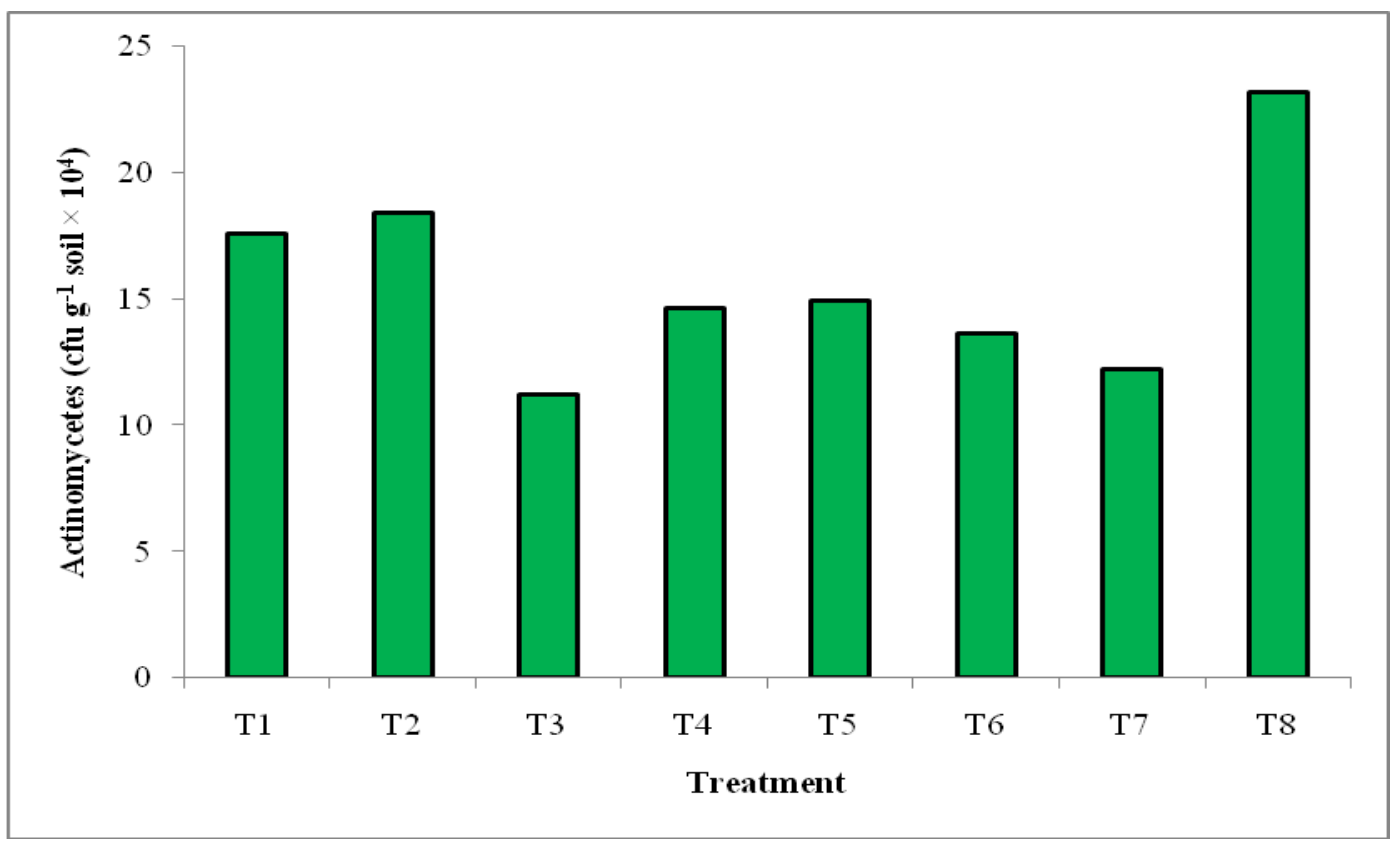


The nutrients released from mineralization of phytomass and $\mathrm{N}$ fixation by legume might result in higher nutrient availability in soil after harvest of crop. On the other hand, $\mathrm{N}$ use efficiency of green manue is high as green manure $\mathrm{N}$ is less prone to loss mechanisms than mineral $\mathrm{N}$ fertilizer and may therefore contribute to enhanced soil N. Green manures increased the availability of $\mathrm{P}$ through the mechanism of reduction and favourable changes in soil $\mathrm{pH}$. Similarly, the green manure mobilizes $\mathrm{S}, \mathrm{P}, \mathrm{Si}, \mathrm{Zn}, \mathrm{Cu}, \mathrm{Mn}$ and other nutrient elements (Selvi and Kalpana, 2009). The enhanced soil nutrients under green manuring viz. available $\mathrm{N}, \mathrm{P}, \mathrm{K}$ and $\mathrm{S}$ (Hebbi, 2000; Sharma et al., 2000; Nooli et al., 2001; Biradar and Palled, 2003; Tsubo et al., 2005; Dahmardeh et al., 2010; Subehia and Dhanika, 2013; Ziblim et al., 2013) have already been reported.

\section{Soil microbial population (Bacteria, fungi and actinomycetes)}

The soil microbial population viz. bacteria, fungi and actinomycetes after harvest of crops has been presented in Figure 1, 2 and 3. The population of soil bacteria ranged from 23.3 to $42.0 \mathrm{cfu} \mathrm{g}^{-1}$ soil $\times 10^{7}$. The highest bacterial population was observed under the treatment $\mathrm{T}_{8}$ (sole sunhemp at $30 \mathrm{~cm}$ ) whereas the lowest was observed under sole maize cultivation at $60 \mathrm{~cm}$ row to row spacing $\left(\mathrm{T}_{6}\right)$. The soil bacterial population was found in the order: Sole green manure>Intercropping with green manure> Intercropping $>$ Sole cropping. The population of soil fungi and actinomycetes ranged between 8.0-18.0 cfu $\mathrm{g}^{-1}$ soil $\times 10^{4}$ and $11.2-23.2 \mathrm{cfu} \mathrm{g}^{-1}$ soil $\times 10^{4}$, respectively under different treatment combinations. The highest fungal and actinomycetes population was found under sole green manure cropping i.e. treatment $T_{8}$ whereas the lowest was observed under $\mathrm{T}_{7}$ (Soybean + Maize $(1: 1)$ at $45 \mathrm{~cm}$ ) and $\mathrm{T}_{3}$ (Sole soybean at $45 \mathrm{~cm}$ ), respectively. The treatments involving sole green manure incorporation $\left(\mathrm{T}_{8}\right)$ and green manure intercropping $\left(\mathrm{T}_{1}, \mathrm{~T}_{2}, \mathrm{~T}_{4}\right.$ and $\left.\mathrm{T}_{5}\right)$ showed significantly higher soil fungal and actinomycetes population as compared to the other treatments (Fig. 2 and 3). It has been observed that the treatments with incorporation of green manure either alone or in combination as intercrop showed significantly higher soil microbial population irrespective of the spacing and type of crop combinations (soybean/maize).

The soil bacterial population was found in the order: Sole green manure>Intercropping with green manure> Intercropping $>$ Sole cropping (Fig. 1). Similarly, the highest fungal and actinomycetes population was found under sole green manure cropping i.e. treatment $T_{8}$ whereas the lowest was observed under $T_{7}$ and $\mathrm{T}_{3}$, respectively. It has been observed that the treatments with incorporation of green manure either alone or in combination as intercrop showed significantly higher soil microbial population irrespective of the spacing and type of crop combinations (soybean/maize). The increased microbial population under green manuring mainly attributed to the higher organic carbon especially biologically active phase of carbon which acted as source of energy for microbes proliferating in soil as reported by Rajannan and Oblisami (1979). Similarly, the significant positive correlation among soil organic carbon and microbial population has already been explored earlier by Graham and Haynes (2005). The enhanced microbial population upon application of different sources of organic matter is in close agreement with present results (Kannan et al., 2006; Aher et al., 2018).

In conclusions, the incorporation of sunhemp as green manure crop intercropped with soybean and maize showed positive response on physic-chemical and microbial properties 
of soil. The green manure intercrop treatments significantly enhanced soil organic carbon and improved physical, chemical and biological properties of soil and reflected as viable technique in improving soil health.

\section{References}

Aher, S. B., Lakaria, B. L., Swami K., Singh, A. B., Ramana, S., Thakur, J. K., Biswas, A. K., Jha, P., Manna, M. C. and Yashona, D. S. 2018. Soil microbial population and enzyme activities under organic, biodynamic and conventional agriculture in semi-arid tropical conditions of central India. Journal of Experimental Biology and Agricultural Sciences, 6(5): 763-773.

Aher, S. B., Lakaria, B. L., Swami K., Singh, A. B., Ramana, S., Ramesh, K. and Thakur, J. K. 2015. Effect of organic farming practices on soil and performance of soybean (Glycine max) under semi-arid tropical conditions in central India. J. Applied and Natural Sci. 7(1): 67-71.

Aulakh, M. S., Khera, T. S., John, W., Doran and Kevin, F. B. 2001. Managing crop residue with green manure, urea and tillage in a rice-wheat rotation. Soil Sci. Soc. Am. J. 65(3): 820-827.

Bardsley, C. E. and Lancaster, I. D. 1960. Determination of reserve sulphur and soluble sulphates in soil. Soil Sci. Soc. Am. Proc. 24: 265-268.

Baur, A. and Black, A. L. 1994. Quantification of the effect of soil organic matter content on soil productivity. Soil Sci. Soc. Am. J. 58: 185-193.

Bharadwaj, S. P., Prasad, S. N. and Singh, G. 1981. Economizing nitrogen by green manures in rice-wheat rotation. Indian J. Agric. Sci. 51: 86-90.

Bin J. 1983. Utilization of green manure for raising soil fertility in China. Soil Sci.
135(1): 65-69.

Biradar, I. B. and Palled, Y. B. 2003. Evaluation of green manuring cover crops for their suitability as year long field covers in hybrid cotton. Karnataka J. Agric. Sci. 16(1): 113-115.

Chand, M., Roy, N and Gupta, J. 2011. Effect of soil fertility improvement practices on yield of wheat (Triticum aestivum L.). Bhartiya Krishi Anushandhan Patrika. 26(3/4): 111-113.

Dahmardeh, M., Ghanbari, A., Syahsar, B. A., and Ramrodi, M. 2010. The Role of Intercropping maize (Zea mays L.) and Cowpea (Vigna unguiculata L.) on yield and Soil Chemical Properties. Afr. J. Agric. Res. 5(8): 631-636.

Dhima, K. V., Lithourgidis, A. S., Vasilakoglou, I. B. and Dordas, C. A. 2007. Competition indices of common vetch and cereal intercrops in two seeding ratio. Field Crops Res. 100: 249-256.

Ghanbari, A., Dahmardeh, M., Siahsar, B. A., and Ramroudi, M. 2010. Effect of Maize (Zea mays L.) - Cowpea (Vigna unguiculata L.) Intercropping on Light Distribution, Soil Temperature and Soil Moisture in Arid Environment. $J$. Food, Agric. Environ. 8(1): 102-108.

Graham, M. H. and Haynes, R. J. 2005. Organic matter accumulation and fertilizer-induced acidification interact to affect soil microbial and enzyme activity on a long-term sugarcane management experiment. Biology and Fertility of Soils. 41: 249-256.

Hayder, G., Mumtaz, S. S., Khan, A. and Khan, S. 2003. Corn and soybean intecropping under various levels of soybean seed rates. Asian Plant sci. 2: 339-341.

Hebbi, B. S. 2000. Influence of in-situ moisture conservation practices in sunnhemp green manuring and levels of nitrogen on rabi sorghum. M. Sc. (Agri.) 
Thesis, Univ. Agric. Sci., Dharwad, Karnataka (India).

Hiremath, S. M. and Patel, Z. G. 1996. Biomass production, $\mathrm{N}$-accumulation and nodulation of green manure species during winter season. J. Maharashtra Agric. Univ. 21: 55-57.

Hongal, M. M. 2001. Effect of green manuring and levels of nitrogen on the performance of chilli + cotton intercrop system. M. Sc. (Agri.) Thesis, Univ. Agric. Sci., Dharwad, Karnataka (India).

Jackson, M. L. 1973. Soil Chemical Analysis, Prentice Hall of India Private Limited, New Delhi, 38- 82.

Kannan, P., Saravanan, A. and Balaji, T. 2006. Organic farming on tomato yield and quality. Crop Res. 32(2): 196-200.

Kuchenbuch, R. O. and Ingram, K. T. 2004. Effects of soil bulk density on seminal and lateral roots of young maize plants (Zea mays L). J. Plant Nutrition and Soil Sci. 167(2): 229-235.

Kumar, V. and Singh, A. P. 2010. Long-term Effect of Green Manuring and Farmyard Manure on Yield and Soil Fertility Status in Rice- Wheat Cropping System. J. Indian Soc. Soil Sci. 58(4): 409-412.

Mishra, B. B. and Nayak, K. C. 2004. Organic farming for sustainable agriculture in orissa. Orissa review. 3: 16-20.

Mucheru-Muna, M., Pypers, P., Mugendi, D., Kung'u, J., Mugwe, J., Merckx, R. and Vanlauwe, B. 2010. A staggered maize legume intercrop arrangement robustly increases crop yields and economic returns in the high lands of Central Kenya. Field Crops Res. 115: 132-139.

Muza, L. 1998. Selecting green-manure legumes for relay and intercropping systems with maize on sandy soils in Zimbabwe. Kenya. 67.

Nooli, S. S., Chittapur, B. M., Hiremath, S. M. and Chimmad, V. P., 2001. Effect of intercropped legume green manures in maize-safflower sequence cropping as soil fertility dynamics. National Seminar on Technology Option for Dryland Agriculture, held from 20-22 November 2001 at AC and RI Madhurai, Tamil Nadu Agric. Univ. 67.

Olsen, S. R., Cole, C. V., Watanable, F. S. and Dean, L. A. 1954. Estimation of available phosphorus in soils by extraction with sodium carbonate. United State Dept. of Agri. Circ. 939: 19.

Panse, V. G. and Sukhatme, R. V. 1967. Statistical Methods for Agriculture Research. I.C.A.R., New Delhi.

Piper, C. S. 1950. Soil and Plant Analysis. Inter science publishers. Inc. New York.

Rajannan, G. and Oblisami, G. 1979. Effect of paper factory effluents on soil and crop plants. Indian J. Environ. Health. 21: 120-130.

Richards, L. A. 1954. Diagnasis and Improvement of Saline and Alkaline Soils USDA Agriculture Handbook 60,Washington D.C

Selvi, R. V. and Kalpana, R. 2009. Potentials of green manure in integrated nutrient management for rice. Agric. Rev. 30(1): 40-47.

Sharma, A. R., Singh, R., Dhyani, S. K. and Dude, R. K. 2010. Effect of live mulching with annual legumes on performance of maize and residual effect on following wheat. Indian J.Agron. 55(3): 177-184.

Sharma, S. N., Prasad, R. and Singh, R. K. 2000. Influence of summer legumes in rice (Oryza sativa) - wheat (Triticum aestivum) cropping system on soil fertility. Indian J. Agric. Sci. 70(5): 357-359.

Singh, F., Kumar, R. and Pal S. 2008. Integrated nutrient management in RiceWheat cropping system for sustainable productivity. $J$. the Indian Soc. of Soil 
Sci. 56(2): 205-208.

Subbiah, B. V. and Asija, G. L. 1956. A rapid method for estimation of nitrogen in soil. Curr. Sci. 26: 259-260.

Subehia, S. K. and Dhanika. 2013. Soil nitrogen fractions and its effect on rice (Oryza sativa) yield under integrated nutrient management in a north-western Himalayan soil. Indian J. Soil Conservation. 4(11): 47-51.

Sur, H. S., Sidhu, A. S., Singh, R., Agarawal, G. C. and Sandhu, K. S. 1993. Longterm effect of green manuring on soil physical properties and production potential in green manure maize-wheat sequence. Ann. Agric. Res. 14: 125-131.

Tiarks, A. E., Mazurak, A. P. and Chesnin, L. 1974. Physical and chemical properties of soil associated with heavy applications of manure from cattle feedlots. Soil Sci. Soc. Am. Proceeding. 38: 826-830.

Tsubo, M. and Walker, S. 2002. A model of radiation interception and use by maize- bean intercrop canopy. Agric. and Forest Meteorology. 110: 203-215.

Tsubo, M., Walker, S. and Ogindo, H. O. 2005. A simulation of cereal-legume intercropping systems for semi-arid regions. I. Model development. Field Crops Res. 93: 10-22.

Walkley, I. A. and Black, C. A. 1934. An examination of the Degtozeff methods for determining the soil organic matter and nitrogen in the soil and a proposed modification of the chromic acid titration method. Soil Sci. 37: 29-38.

Yoder, R. E. 1936. A direct methods of aggregate analysis and, study of the physical nature of erosion losses. J. Am. Soc. Agron. 28: 237-251.

Ziblim, I. A., Paul, G. S. and Timothy, K. A. 2013. Assessing soil amendment potentials of Mucuna pruriens and Crotalaria juncea when used as fallow crops. J. Soil Sci. Environ. Manage. 4: 28-34.

\section{How to cite this article:}

Divya Bhayal, V.K. Khaddar, Lalita Bhayal, Tikam Chand Yadav, K.S. Bangar and Bharat Singh. 2018. Effect of Sunhemp Green Manuring and Intercropping on Soil Properties. Int.J.Curr.Microbiol.App.Sci. 7(12): 371-384. doi: https://doi.org/10.20546/ijcmas.2018.712.046 